\title{
«Единство многообразия» как конкурентное преимущество ЕАЭС
}

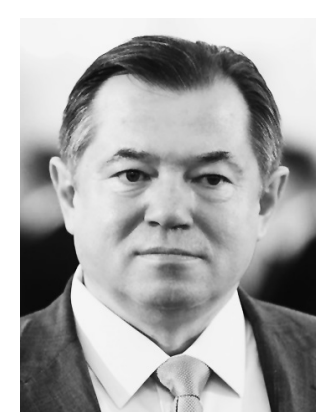

Осмысление предшествующего периода евразийского интеграционного строительства в рамках ЕАЭС позволяет дать исчерпывающую характеристику не только сугубо экономическим параметрам становления Союза, включая многочисленные «узкие места», препятствующие реализации конкурентных преимуществ объединения, но и определить, чего именно не хватает нам во внеэкономической плоскости для того, чтобы состояться и динамично продвигаться по пути сбалансированного и гармоничного соразвития. Иными словами, во избежание экивоков, накопления изъятий из режима функционирования единого экономического пространства с эффективными четырьмя свободами следует построить подлинное «трансграничное пространство доверия». В Стратегических направлениях развития евразийской экономической интеграции до 2025 г. под этим оборотом понимается сложносоставной процесс уточнения договорно-правовой базы Союза, четкость и прозрачность «требований к механизмам обеспечения информационного взаимодействия хозяйствующих субъектов с органами государственной власти государств-членов».

Говоря о пространстве доверия как таковом, я бы предложил его расширительную трактовку, предполагающую развитие интеграции на принципах взаимного доверия, сотрудничества, купирования потенциально конфликтных ситуаций еще до их возникновения, поддержки сторонами друг друга без вынесения споров и противоречий в повестку интеграционной «пятерки». Для этого государства-члены должны в полной мере осознать себя частями единого целого ЕАЭС, а уже после - участниками торгово-экономических отношений, пусть и со стратегическими, но партнерами из третьих стран. Интересы построения крепкого и устойчивого к потрясениям объединения должны превалировать над национальным эгоизмом, тем более что интеграционное поле ограничено исключительно теми сферами, где стороны договорились действовать сообща, а сам Союз построен исключительно на принципах незыблемости национального суверенитета, добровольности, недискриминации и невмешательства во внутренние дела друг друга. Несмотря на то, что принципы взаимного уважения и равенства государств-членов в объединении надежно закреплены договорно-правовой базой ЕАЭС, периодически возникают поводы для недоверия и упреков, как это наблюдалось в диалоге между Россией и Беларусью или Казахстаном и Киргизией.

Упрочение несущих конструкций ЕАЭС во многом будет зависеть от лидерства России в приглашении партнеров к формированию идейно-смысловой среды Союза, что предполагает как актуализацию общего культурно-исторического и духовного наследия, так и совместную выработку привлекательного образа будущего и гармоничного сосуществования на достаточно продолжительном временном отрезке. Русский философ Н. С. Трубецкой еще в 1927 г., рассуждая о перспективах постсоветской России, писал, что основой нового объединения народов станет понимание общих интересов на основе многовековой истории и опыта совместной жизни в рамках единой государственности. При этом он подчеркивал необходимость равенства всех воссоединяющихся народов в новом образовании, а также указывал на угрозы национализма. Нейтрализация последних требует значительных усилий по формированию 
правильного понимания истории, позитивной интерпретации общего исторического опыта как основы формирования оптимистического образа общего будущего и его совместного созидания.

Новые научные достижения в области математической обработки исторических данных подтверждают историческое родство народов Евразии, большую часть времени проживавших в рамках обширных государственных образований - империй и единого экономического пространства, имеющих общие генетические, языковые, культурные и духовные корни. Они также доказывают ключевое значение Евразии в развитии человечества, доминирование евразийских империй в ходе всего цивилизационного строительства вплоть до недавнего времени. Наличие такого исторического фундамента позволяет восполнить бреши в интеграционном строительстве и наполнить реальным содержанием идею Большого евразийского партнерства (далее - БЕП) как формы продуктивного сотрудничества в целях формирования нового мирохозяйственного уклада. Предложенная руководством КНР формула «народов одной исторической судьбы человечества» подтверждает высказанную столетие назад русскими философами идею евразийской интеграции на основе общего исторического опыта народов Евразии.

БЕП создается людьми разных народов для расширения возможностей своего развития и подъема благосостояния на основе сочетания конкурентных преимуществ и объединения имеющихся в изобилии ресурсов Евразии. Это требует разработки и донесения до общественного сознания стран БЕП идеологии широкой евразийской интеграции, которая должна объяснять преимущества жизни в едином экономическом пространстве и позитивно трактовать общую историю совместной жизни, доказывать, что только общими усилиями наши народы сумели построить великие цивилизации в прошлом, сохранить себя перед угрозами интервенций и внешнего порабощения, победить в войнах с общими врагами, обеспечить достойную жизнь людям. Большое значение в этом имеет создание соответствующих сложности сопрягаемых народнохозяйственных организмов условий для кооперации региональных производственно-технологических систем, сочетающих конкурентные преимущества стран Евразии.

Следует совместно с партнерами по ЕАЭС разработать программу научных исследований, культурно-просветительской деятельности, направленную на формирование и содержательное наполнение идеологии евразийской интеграции. Программа такой совместной научной работы специалистов разных стран должна предусматривать проведение междисциплинарных исследований, включающих применение современных математических методов исторической хронологии, социальной психологии, эволюционной экономики, лингвистики, философии, теории государства и права. Эти исследования не только заложат научную основу для разработки евразийской идеологии, но и создадут задел для появления новой научной парадигмы в обществознании с большим количеством прикладных приложений. В том числе в области педагогики, социальной инженерии, культурного строительства, борьбы с экстремизмом и терроризмом, интеграционной политики.

Уже сейчас очевидно, что, запустив Евразийский союз как экономическое пространство с единообразным нормативно-правовым регулированием и согласованными отраслевыми политиками развития, недостаточно внимания было уделено развитию общественных связей, пропаганде интеграции, поддержке межнациональной коммуникации. Между тем «значимым фактором, способствующим сближению и интеграции стран, является реальная коммуникация между их гражданами. В частности, более 80\% граждан Армении и Кыргызстана, порядка 50\% граждан Казахстана и Беларуси поддерживают постоянную связь с родственниками, друзьями и коллегами в соседних по региону СНГ странах, прежде всего в России. Это верно также для 68\% граждан Таджикистана и 58\% граждан Молдовы. При этом 62\% россиян не поддерживают связь с кем-либо за рубежом» (Винокуров Е. Ю., Демиденко М. В., Коршунов Д. А. и др. Евразийская экономическая стратегия - 2017. СПб. : ЦИИ ЕАБР, 2017. С. 81). Очевидно, что наименьший уровень общественной поддержки интеграции в стране, которая выступает в роли лидера этого процесса, прямо связан с недостаточным знанием россиянами реалий политической, экономической, социальной, культурной жизни соседних народов и может быть скорректирован только целенаправленными усилиями по интенсификации международной коммуникации, прежде всего культурной, научной, профессиональной. 
Несмотря на само собой разумеющееся «единство многообразия» - особенности общественнополитических формаций и присущие народам Евразии культурные отличия, неоспоримым является то обстоятельство, что все без исключения страны ЕАЭС придерживаются традиционных консервативных ценностей (семья, религия, духовность, сообщество) в противовес неолиберальным ценностям (индивидуализм, секуляризм, потребительство, мультикультурность, сети вместо сообществ). Такая идейно-мировоззренческая позиция является еще одной точкой единения для воплощения интеграционных целей и задач. ЕАЭС сегодня располагает всем необходимым для того, чтобы состояться как значимый центр силы не только на субконтинентальном уровне, но и в контексте встраивания в глобальные цепочки добавленной стоимости. Граждане ЕАЭС комплементарно настроены к идее упрочения межгосударственных народнохозяйственных связей и межкультурной коммуникации. Турбулентность, обусловленная ускоряющейся агонией старого мирового порядка и появлением привлекательной и дееспособной общественно-государственной и экономической модели в рамках нового - интегрального - мирохозяйственного уклада, постулирует дилемму: порознь или сообща. Позитивный пример сотрудничества в ЕАЭС и обретение интегрируемыми экономиками дополнительных источников роста и преимуществ за счет интеграции стимулируют интерес к объединению со стороны других государств СНГ и - шире Большой Евразии.

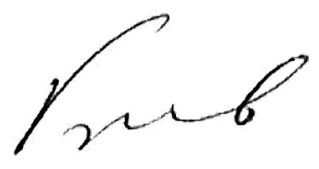

Сергей Глазьев, главный редактор, академик РАН 